\title{
FORMULASI SEDIAAN SERUM ANTIOKSIDAN DARI EKSTRAK SARI TOMAT (Solanum lycopersicum L.) DAN EKSTRAK KAYU MANIS (Cinnamomum burmannii) SEBAGAI PERAWATAN KULIT
}

\author{
Evy Lestari Ariyanti' ${ }^{1}$, Reti Puji Handayani2 ${ }^{*}$, Elih Sutisna Yanto $^{3}$ \\ 1,2,3 Sekolah Tinggi Ilmu Kesehatan Holistik
}

*Korespondensi: Jl. Veteran No. 272, Ciseureuh. Purwakarta. Email: retipunya@gmail.com

\begin{abstract}
ABSTRAK
Latar belakang: Tomat (Lycopersicum esculentum Mill) merupakan salah satu sumber antioksidan yang alami. Tomat kaya akan vitamin A dan $\mathrm{C}$, beta-karoten, kalium dan antioksidan likopen. Selain tomat, kayu manis juga berkhasiat sebagai antioksidan. Penggunaan tomat dan kayu manis secara langsung pada kulit dinilai kurang efektif sehingga perlu diformulasi dalam bentuk serum.

Tujuan: Penelitian ini bertujuan untuk mengetahui cara pembuatan serum tomat dan kayu manis serta mengetahui stabilitas dari serum dilihat dari uji organoleptik, uji homogenitas,uji stabilitas $\mathrm{pH}$ dan uji kesukaan.

Metode: Penelitian ini menggunakan metode penelitian tindakan (Action Researh). Sediaan dibuat dengan komposisi ekstrak sari buah tomat dan ekstrak kayu manis dengan perbandingan 3 gram : 0,5 gram serta penambahan 1 gram xanthan gum untuk F1, 1,2 gram untuk F2, 1,4 gram untuk F3.

Hasil : Hasil uji organoleptik yang telah dilakukan menunjukan adanya perubahan pada hari ke-9 sampai ke-21. Hasil stabilitas $\mathrm{pH}$ yang diperoleh dari 3 sampel serum menunjukan hasil pada minggu ke-2 terjadi perubahan $\mathrm{pH}$ pada sediaan yang disimpan di suhu ruang $\left(15-30^{\circ} \mathrm{C}\right)$. Hasil uji kesukaan serum untuk tekstur sebanyak 93,3\% pada formula 1 . Warna $97 \%$ pada formula 1 dan aroma sebanyak $83,3 \%$ pada formula 2 .

Simpulan : Hasil uji organoleptik dan uji kesukaan formula unggulan adalah F1, sedangkan hasil uji homogenitas ketiga sedian yang disimpan selama 3minggu dalam keadaan homogen. Hasil uji $\mathrm{pH}$ sediaan masih dalam batas $\mathrm{pH}$ kulit.
\end{abstract}

Kata kunci: Kayu manis , Serum, Tomat.

\begin{abstract}
Background: Tomato (Lycopersicum esculentum Mill) is a natural source of antioxidants. Tomatoes are rich in vitamins $A$ and $C$, beta-carotene, potassium and the antioxidant lycopene. Apart from tomatoes, cinnamon also has antioxidant properties. The use of tomatoes and cinnamon directly on the skin is considered ineffective, so it needs to be formulated in serum.

Objective: This research to determine how to make tomato and cinnamon serum and to determine the stability of the serum seen from the organoleptic test, homogeneity test, $\mathrm{pH}$ stability test and preference test.

Methods: This research uses action research method (Action Research). The preparation is made with a composition of tomato juice extract and cinnamon extract with a ratio of 3 grams: 0.5 grams and the addition of 1 gram of xanthan gum for F1, 1.2 grams for F2, 1.4 grams for F3.

Results: The Results of the organoleptic tests which have been performed showed the presence of changes on the 6th day until the 21st. The pH stability results obtained from 3 serum samples showed that at week 2 there was a change in $\mathrm{pH}$ in the preparations stored at room temperature $\left(15-30^{\circ} \mathrm{C}\right)$. The result of the serum preference test for texture of as much $93.3 \%$ in formula 1. the colors of serum 97\% in formula 1 and fragrance of as $83.3 \%$
\end{abstract}


in formula 2.

Conclusion: the Results of organoleptic test and test favorite formula featured is F1, while the results of the third homogeneity test were stored for 3 weeks in a homogeneous state. The $\mathrm{pH}$ test results are still within the skin $\mathrm{pH}$.

Keywords: Cinnamon, Serum, Tomato.

\section{PENDAHULUAN}

Antioksidan merupakan senyawa yang dapat menghambat reaksi oksidasi, dengan mengikat radikal bebas dan molekul yang sangat reaktif sehingga kerusakan sel akan dihambat dan sering dimanfaatkan untuk mencegah penuaan dini. Antioksidan terdapat dalam beberapa bentuk, diantaranya vitamin, mineral, dan senyawasenyawa metabolit sekunder lainnya pada tumbuhan yang memiliki aktivitas antioksidan, salah satunya adalah buah tomat.

Tomat (Lycopersicum esculentum Mill) merupakan salah satu sumber antioksidan yang alami. Hasil penelitian menunjukkan bahwa mengkonsumsi tomat secara teratur dapat mengurangi risiko beberapa jenis kanker [3]. Tomat memiliki berbagai vitamin dan senyawa anti penyakit yang baik bagi kesehatan, terutama likopen. Tomat mengandung lemak dan kalori dalam jumlah rendah, bebas kolesterol, dan merupakan sumber serat dan protein yang baik. Selain itu, tomat kaya akan vitamin A dan C, beta-karoten, kalium dan antioksidan likopen. Satu buah tomat ukuran sedang mengandung hampir setengah batas jumlah kebutuhan harian (required daily allowance/RDA) vitamin $\mathrm{C}$ untuk orang dewasa [1].

Kulit merupakan organ yang menutupi seluruh tubuh manusia, dan mempunyai daya proteksi terhadap pengaruh luar. Kulit sangat mendukung penampilan seseorang sehingga perlu dirawat, dipelihara, dan dijaga kesehatannya. Dengan perawatan dan pemeliharaan, maka penampilan kulit akan terlihat sehat, terawat, serta senantiasa memancarkan kesegaran [5].

Selain tomat, kayu manis juga berkhasiat sebagai antioksidan. Penggunaan tomat dan kayu manis secara langsung pada kulit dinilai kurang efektif sehingga perlu diformulasi dalam bentuk serum.

\section{METODE PENELITIAN}

Penelitian ini menggunakan desain penelitian tindakan (Action Researh). Action Research adalah kegiatan dan atau tindakan perbaikan sesuatu yang perencanaan, pelaksanaan, dan evaluasinya digarap secara sistematik sehingga validitas dan reliabilitasnya mencapai tingkatan riset.Action research juga merupakan proses yang mencakup siklus aksi, yang mendasarkan pada refleksi; umpan balik (feedback); bukti (evidence); dan evaluasi atas aksi sebelumnya dan situasi sekarang [2]. Tindakan yang dilakukan dalam penelitian ini adalah dengan mengkombinasi ekstrak tomat dan ekstrak kayu manis dengan tujuan untuk mengetahui kestabilan sediaan.

\section{ALAT DAN BAHAN}

Alat yang digunakan dalam penelitian ini adalah Gelas ukur $100 \mathrm{ml}$, Beaker glass 150 ml, Blender, Pisau, Kertas saring, Timbangan, Mortir dan stemper, Cawan penguap, Wadah serum.

Bahan yang digunakan dalam pembuatan serum adalah ekstrak sari tomat (Solanum lycopersicum L.), Ekstrak kayu manis (Cinnamomum burmannii), dan Xanthan gum sebagai basis serum.

\section{CARA KERJA}

\section{Pembuatan Ekstrak Sari Tomat (Solanum lycopersicum L.)}

Buah tomat di cuci sampai bersih, kemudian di potong kecil - kecil lalu di bleder. Sari/jus tomat dimasukkan dalam wadah maserasi, kemudian ditambahkan etanol 96\% hingga sampel terendam. Kemudian ditutup dan disimpan selama 24 
jam ditempat gelap yang terlindung cahaya sambil sesekali diaduk. Selanjutnya disaring, dipisahkan ampas dan filtratnya. Ampas kembali diekstraksi dengan etanol dengan perlakuan yang sama sebanyak $3 \mathrm{x}$ 24 jam. Kemudian ekstrak etanol yang diperoleh diuapkan sampai diperoleh ekstrak etanol kental.

\section{Pembuatan Ekstrak Kayu manis (Cinnamomum burmannii).}

Serbuk halus kayu manis dimaserasi dengan pelarut etanol $96 \%$ dengan ketinggian pelarut $\pm 1 \mathrm{~cm}$ diatas sampel. Maserasi dilakukan sebanyak 3 kali masing- masing selama 24 jam pada suhu kamar. Hasil dari maserasi tersebut disaring dan filtrat yang dihasilkan ditampung. Filtrat yang sudah diperoleh tadi kemudian diuapkan hingga memperoleh ekstrak kental.

\section{Formulasi sediaan serum ekstrak sari tomat dan ekstrak kayu manis}

Sediaan dibuat dengan komposisi ekstrak sari buah tomat dan ekstrak kayu manis dengan perbandingan 3 gram : 0,5 gramserta penambahan 1 gram xanthan gum untuk F1sebnyak 1,2 gram untuk F2 dan F3 sebanyak 1,2 dan 1,4.

Tabel 1. Formulasi Sediaan

\begin{tabular}{cccc}
\hline Bahan & F1 & Persentase (\%) & F3 \\
& 3 & F2 & 3 \\
Tomat & 0,5 & 3 & 0,5 \\
Kayumanis & 1 & 0,5 & 1,4 \\
Xanthan gum & Ad $100 \mathrm{ml}$ & 1,2 & $\mathrm{Ad} 100 \mathrm{ml}$ \\
Aquadest & & Ad $100 \mathrm{ml}$ & \\
\hline
\end{tabular}

\section{Pembuatan sediaan Serum}

Xanthan gum didispersikan dalam aqua destilata hingga terbentuk massa serum. Tambahkan ekstrak kayu manis ke dalam massa serum yang telah terbentuk didalam mortir. Basis serum yang telah terbentuk selanjutnya dimasukkan ekstrak sari buah tomat lalu digerus hingga homogen. Tambahkan aquadest ad $100 \mathrm{ml}$ hingga larut. Masukan serum yang sudah jadi ke dalam wadah lalu kemas dengan rapi.

\section{Uji Stabilitas Fisik}

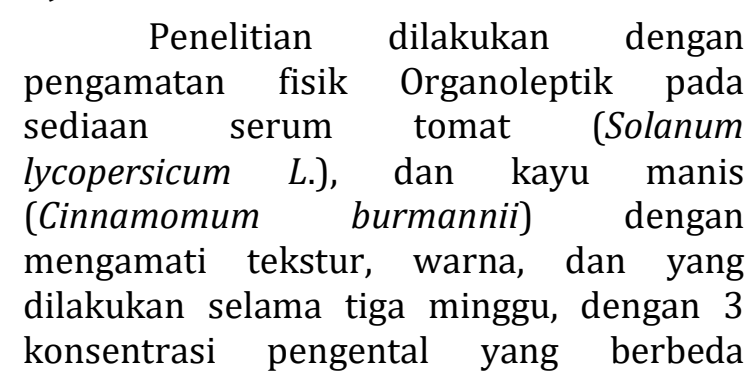

disimpan pada suhu ruangan yaitu $15-30^{\circ} \mathrm{C}$ dan suhu dingin $2-8^{\circ} \mathrm{C}$.

Uji homogenitas dilakukan dengan cara serum diambil secukupnya kemudian dioleskan pada plat kaca, diraba, dan digosokkan, massa serum harus menunjukkan susunan homogen yaitu tidak terasa adanya bahan padat pada kaca [6].

Uji pH dilakukan dengan cara mencelupkan kertas $\mathrm{pH}$ pada sediaan serum, kemudian diamati ada tidaknya perubahan warna pada kertas $\mathrm{pH}$. Tujuannya adalah mengukur derajat keasaman pada serum untuk menjamin sediaan serum tidak menyebabkan iritasi pada kulit.

Uji kesukaan dilakukan dengan meminta tanggapan kepada 30 responden. Data hasil penelitian di analisis menggunakan Teknik observasi kualitatif yaitu pencatatan serta dokumentasi selama pengujian hingga akhir pengujian. 


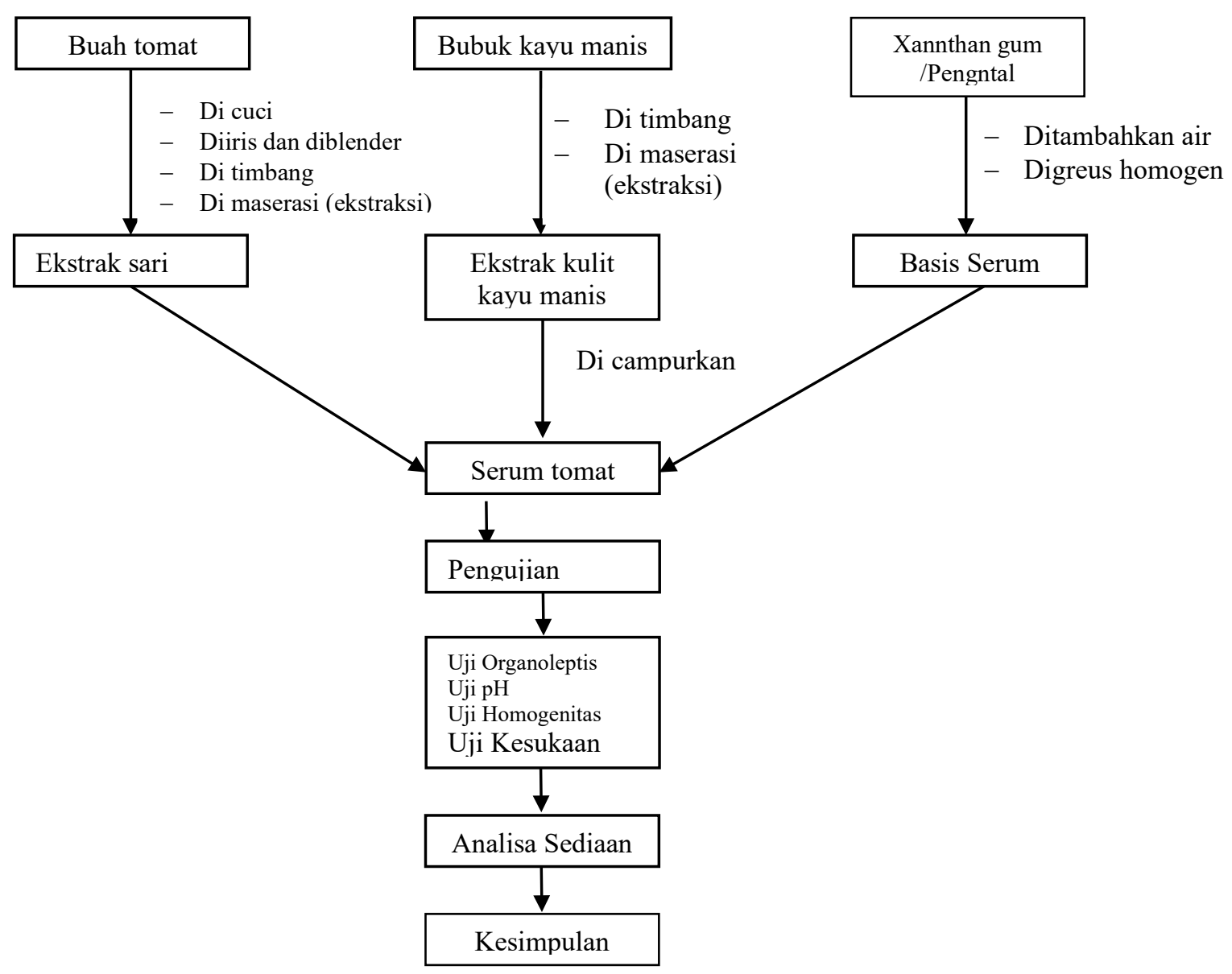

Gambar 1. Proses pembuatan Serum

\section{HASIL PENELITIAN}

\section{Hasil Formulasi}

Formulasi yang dibuat dengan komposisi serum ekstrak sari tomat dan kayu manis diantaranya F1 (ekstrak sari tomat 3 gram, ekstrak kayu manis 0,5 gram, xanthan gum 1 gram, dan air $100 \mathrm{ml}$ ), F2 (ekstrak sari tomat 3 gram, ekstrak kayu manis 0,5 gram, xanthan gum 1,2 gram, dan air $100 \mathrm{ml}$ ), F3 (ekstrak sari tomat 3 gram,

Ekstrak kayu manis 0,5 gram, xanthan gum 1,4 gram, dan air $100 \mathrm{ml}$ ). Serum ekstrak sari tomat dan kayu manis pada F1 dari warnanya yaitu coklat muda, baunya mengeluarkan aroma tomat dan sedikit kayu manis, dan teksturnya kental seprti gel. F2 warnanya coklat agak tua , baunya mengeluarkan aroma tomat da kayu manis, sedangkan teksturnya agak kental. F3 warnanya coklat agak tua, baunya mengeluarkan aroma tomat dan kayu manis kemudian teksturnya kental.

\section{Hasil Uji Organoleptik}

Hasil uji Organoleptik tertera pada Tabel 2. suhu kamar $\left(15-30^{\circ} \mathrm{C}\right)$ dan table 3 . suhu dingin $\left(2-8^{\circ} \mathrm{C}\right)$ di bawah ini : 
Tabel 2. Hasil Uji Organoleptik pada suhu kamar $\left(15-30^{\circ} \mathrm{C}\right)$

\begin{tabular}{|c|c|c|c|c|c|c|c|c|c|}
\hline \multirow[t]{2}{*}{ Sample } & \multirow[t]{2}{*}{ Pengamatan } & \multicolumn{8}{|c|}{ Hari ke- } \\
\hline & & 1 & 3 & 6 & 9 & 12 & 15 & 18 & 21 \\
\hline \multirow[t]{3}{*}{$\mathrm{F} 1$} & Warna & $\begin{array}{l}\text { Coklat } \\
\text { muda }\end{array}$ & $\begin{array}{l}\text { Coklat } \\
\text { muda }\end{array}$ & $\begin{array}{l}\text { Coklat } \\
\text { muda }\end{array}$ & $\begin{array}{l}\text { Coklat } \\
\text { muda }\end{array}$ & $\begin{array}{l}\text { Coklat } \\
\text { muda }\end{array}$ & $\begin{array}{l}\text { Coklat } \\
\text { muda }\end{array}$ & $\begin{array}{l}\text { Coklat } \\
\text { muda }\end{array}$ & $\begin{array}{l}\text { Coklat } \\
\text { muda }\end{array}$ \\
\hline & Bau & $\begin{array}{l}\text { Aroma } \\
\text { tomat,sed } \\
\text { ikit kayu } \\
\text { manis }\end{array}$ & $\begin{array}{l}\text { Aroma } \\
\text { tomat } \\
\text { sedikit } \\
\text { kayu } \\
\text { manis }\end{array}$ & $\begin{array}{c}\text { Aroma } \\
\text { tomat } \\
\text { sedikit } \\
\text { kayu } \\
\text { manis }\end{array}$ & $\begin{array}{c}\text { Sedikit } \\
\text { aroma } \\
\text { tomat }\end{array}$ & $\begin{array}{l}\text { Sedikit } \\
\text { aroma } \\
\text { tomat }\end{array}$ & $\begin{array}{c}\text { Sedikit } \\
\text { aroma } \\
\text { tomat }\end{array}$ & $\begin{array}{l}\text { Sedikit } \\
\text { aroma } \\
\text { tomat }\end{array}$ & $\begin{array}{c}\text { Sedikit } \\
\text { aroma } \\
\text { tomat }\end{array}$ \\
\hline & Tekstur & $\begin{array}{l}\text { Kental } \\
\text { seperti } \\
\text { gel }\end{array}$ & $\begin{array}{l}\text { Kental } \\
\text { seperti } \\
\text { gel }\end{array}$ & $\begin{array}{l}\text { Kental } \\
\text { seperti } \\
\text { gel }\end{array}$ & $\begin{array}{l}\text { Kental } \\
\text { berair }\end{array}$ & $\begin{array}{l}\text { Kental } \\
\text { berair }\end{array}$ & $\begin{array}{l}\text { Kental } \\
\text { berair }\end{array}$ & $\begin{array}{l}\text { Kental } \\
\text { berair }\end{array}$ & $\begin{array}{l}\text { Kental } \\
\text { berair }\end{array}$ \\
\hline \multirow[t]{4}{*}{$\mathrm{F} 2$} & Warna & $\begin{array}{c}\text { Coklat } \\
\text { agak tua }\end{array}$ & $\begin{array}{c}\text { Coklat } \\
\text { agak tua }\end{array}$ & $\begin{array}{l}\text { Coklat } \\
\text { agak tua }\end{array}$ & $\begin{array}{c}\text { Coklat } \\
\text { agak } \\
\text { tua }\end{array}$ & $\begin{array}{c}\text { Coklat } \\
\text { agak } \\
\text { tua }\end{array}$ & $\begin{array}{c}\text { Coklat } \\
\text { agak } \\
\text { tua }\end{array}$ & $\begin{array}{c}\text { Coklat } \\
\text { agak } \\
\text { tua }\end{array}$ & $\begin{array}{c}\text { Coklat } \\
\text { agak } \\
\text { tua }\end{array}$ \\
\hline & Bau & $\begin{array}{c}\text { Aroma } \\
\text { tomat } \\
\text { kayu } \\
\text { manis }\end{array}$ & $\begin{array}{l}\text { Aroma } \\
\text { tomat } \\
\text { kayu } \\
\text { manis }\end{array}$ & $\begin{array}{l}\text { Aroma } \\
\text { tomat } \\
\text { kayu } \\
\text { manis }\end{array}$ & $\begin{array}{c}\text { Aroma } \\
\text { tomat } \\
\text { kayu } \\
\text { manis }\end{array}$ & $\begin{array}{c}\text { Aroma } \\
\text { tomat } \\
\text { kayu } \\
\text { manis }\end{array}$ & $\begin{array}{c}\text { Aroma } \\
\text { tomat } \\
\text { kayu } \\
\text { manis }\end{array}$ & $\begin{array}{c}\text { Aroma } \\
\text { tomat } \\
\text { kayu } \\
\text { manis }\end{array}$ & $\begin{array}{c}\text { Aroma } \\
\text { tomat } \\
\text { kayu } \\
\text { manis }\end{array}$ \\
\hline & Tekstur & Agak & Agak & Agak & Agak & Agak & Agak & Agak & Agak \\
\hline & & kental & kental & kental & kental & kental & kental & kental & kental \\
\hline \multirow[t]{3}{*}{ F3 } & Warna & $\begin{array}{c}\text { Coklat } \\
\text { agak tua }\end{array}$ & $\begin{array}{l}\text { Coklat } \\
\text { agak tua }\end{array}$ & $\begin{array}{l}\text { Coklat } \\
\text { agak tua }\end{array}$ & $\begin{array}{c}\text { Coklat } \\
\text { agak } \\
\text { tua }\end{array}$ & $\begin{array}{c}\text { Coklat } \\
\text { agak } \\
\text { tua }\end{array}$ & $\begin{array}{c}\text { Coklat } \\
\text { agak } \\
\text { tua }\end{array}$ & $\begin{array}{c}\text { Coklat } \\
\text { agak } \\
\text { tua }\end{array}$ & $\begin{array}{c}\text { Coklat } \\
\text { agak } \\
\text { tua }\end{array}$ \\
\hline & Bau & $\begin{array}{c}\text { Aroma } \\
\text { tomat } \\
\text { kayu } \\
\text { manis }\end{array}$ & $\begin{array}{l}\text { Aroma } \\
\text { tomat } \\
\text { kayu } \\
\text { manis }\end{array}$ & $\begin{array}{l}\text { Aroma } \\
\text { tomat } \\
\text { kayu } \\
\text { manis }\end{array}$ & $\begin{array}{c}\text { Aroma } \\
\text { tomat } \\
\text { kayu } \\
\text { manis }\end{array}$ & $\begin{array}{c}\text { Aroma } \\
\text { tomat } \\
\text { kayu } \\
\text { manis }\end{array}$ & $\begin{array}{c}\text { Aroma } \\
\text { tomat } \\
\text { kayu }\end{array}$ & $\begin{array}{c}\text { Aroma } \\
\text { tomat } \\
\text { kayu }\end{array}$ & $\begin{array}{c}\text { Aroma } \\
\text { tomat } \\
\text { kayu }\end{array}$ \\
\hline & Tekstur & Kental & Kental & Kental & Kental & Kental & Kental & Kental & Kental \\
\hline
\end{tabular}

Tabel 7. Hasil Uji Organoleptik pada suhu dingin $\left(2-8^{\circ} \mathrm{C}\right)$

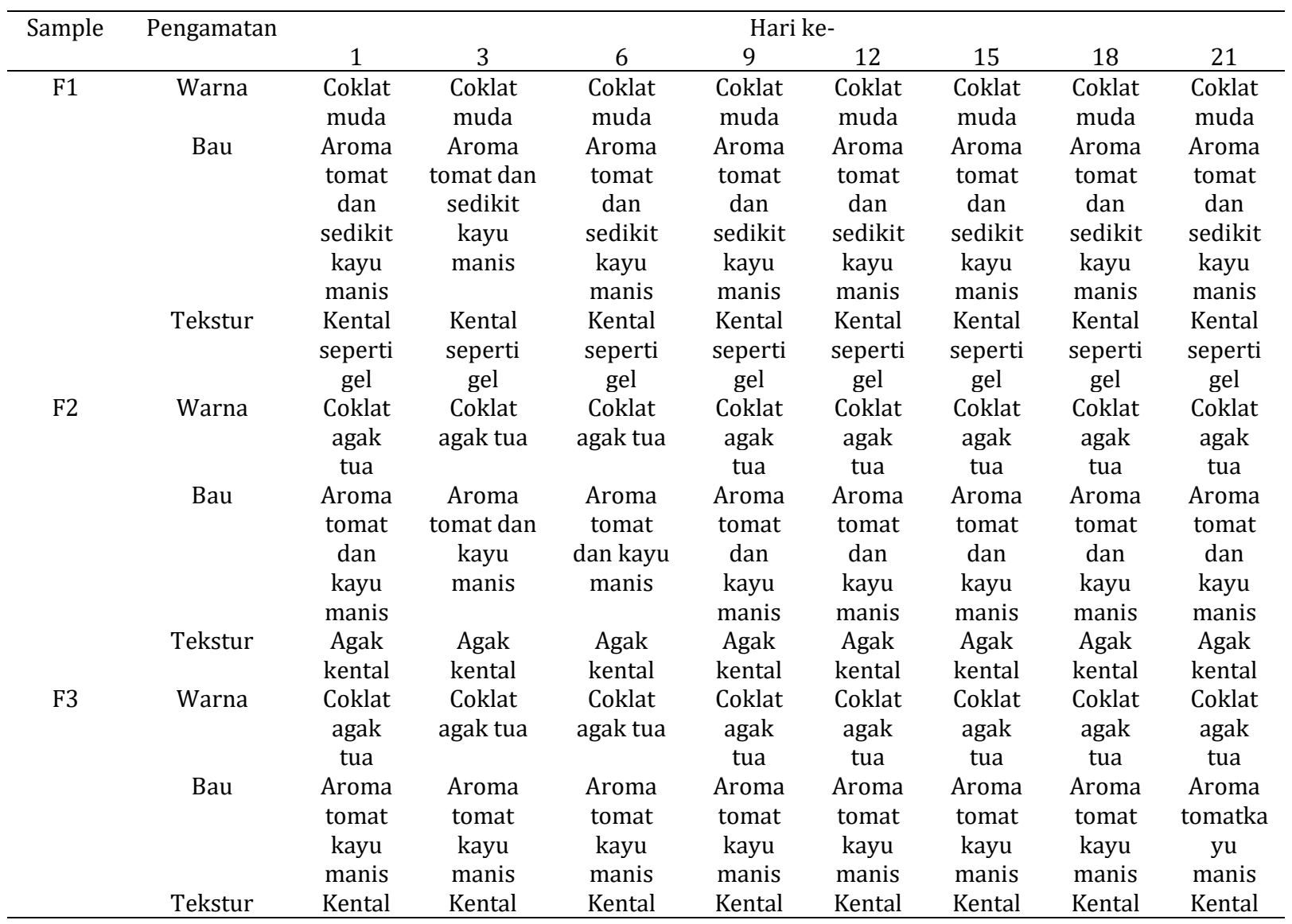




\section{Hasil Uji Homogenitas}

Tabel 4. Hasil Uji Homogenitas

\begin{tabular}{cc}
\hline Sample & Hasil Evaluasi \\
\hline F1 & Homogen \\
F2 & Homogen \\
F3 & Homogen \\
\hline
\end{tabular}

\section{Hasil Uji Kesukaan}

Tabel 5. Hasil Uji Kesukaan

\begin{tabular}{ccccccc}
\hline Jenis yang di uji & Kode sample & \multicolumn{5}{c}{ Skor } \\
& & STS & TS & N & S & SS \\
\hline Tekstur & F1 & - & - & $6,7 \%$ & $93,3 \%$ & - \\
& F2 & - & $80 \%$ & $13,3 \%$ & $6,7 \%$ & - \\
Warna & F3 & - & $97 \%$ & $3 \%$ & - & - \\
& F1 & - & & $3 \%$ & $97 \%$ & - \\
\multirow{3}{*}{ Aroma } & F2 & - & $83,3 \%$ & $16,7 \%$ & - & - \\
& F3 & - & $93,3 \%$ & $6,7 \%$ & - & - \\
& F1 & - & $16,7 \%$ & $40 \%$ & $43,3 \%$ & - \\
& F2 & - & - & $16,7 \%$ & $83,3 \%$ & - \\
& F3 & - & $30 \%$ & $23,3 \%$ & $46,7 \%$ & - \\
\hline
\end{tabular}

Tabel 5 menunjukan hasil uji kesukaan sediaan Serum)yang telah diuji dan diamati dari 30 responden. Parameter pertama yaitutekstur, yang tidak suka dengan tekstur serumsebanyak $80 \%$ pada formula 2 dan $97 \%$ pada formula 3 , sedangkan yang suka dengan tekstur serumsebanyak 93,3\%\% pada formula 1 . Parameter kedua yaitu warna serum sebanyak 83,3\% yang tidak suka dengan warna pada formula 2 dan 93,3\% pada formula 3, sedangan kan sebanyak 97\% suka dengan warna pada formula 1 . Parameter ketiga yaitu aroma, sebanyak $16,7 \%$ tidak suka dengan aroma serum pada formula 1 . Sebanyak $83,3 \%$ suka aroma serum pada formula 2 .

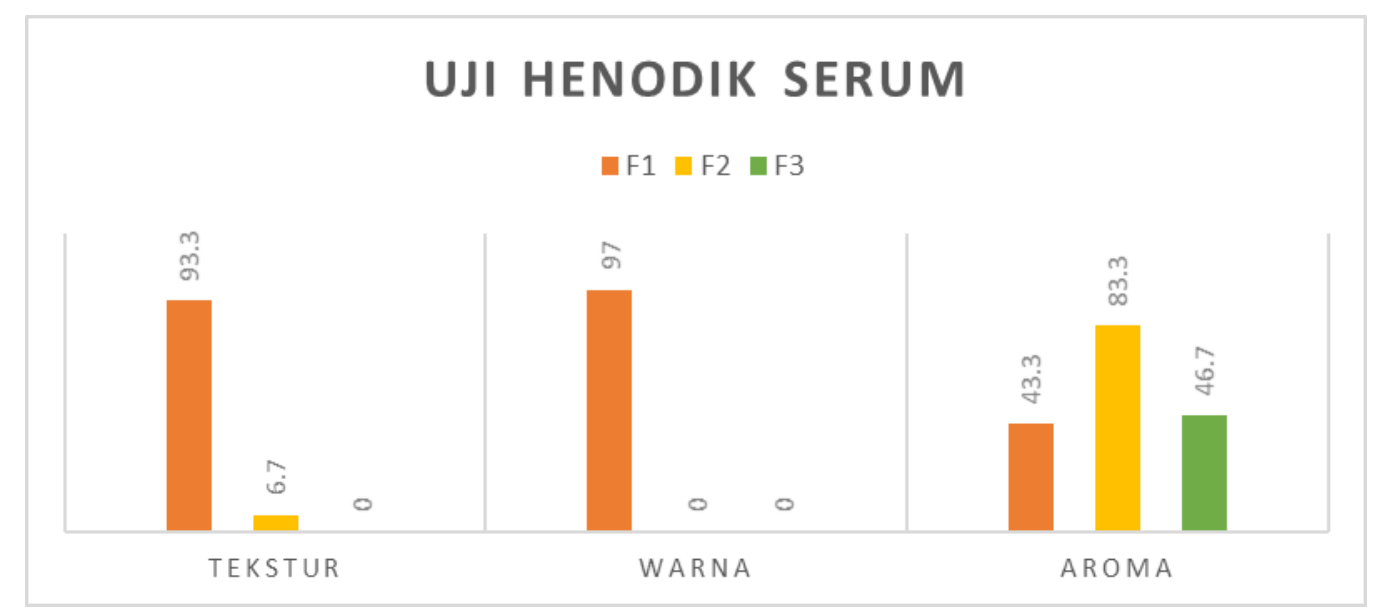

Gambar 3. Diagram Uji Kesukaan Serum 
Tabel 6. Pengujian pH

\begin{tabular}{ccccccccc}
\hline Sample & \multicolumn{3}{c}{$\begin{array}{c}\text { Suhu ruang }\left(15-30^{\circ} \mathrm{C}\right) \\
\text { Minggu ke- }\end{array}$} & \multicolumn{4}{c}{$\begin{array}{c}\text { Suhu dingin }\left(2-8^{\circ} \mathrm{C}\right) \\
\text { Minggu ke- }\end{array}$} \\
\cline { 2 - 8 } & $\mathbf{0}$ & $\mathbf{1}$ & $\mathbf{2}$ & $\mathbf{3}$ & $\mathbf{0}$ & $\mathbf{1}$ & $\mathbf{2}$ & $\mathbf{3}$ \\
F1 & 5 & 5 & 7 & 7 & 5 & 5 & 5 & 6 \\
F2 & 5 & 5 & 6 & 6 & 5 & 5 & 5 & 5 \\
F3 & 5 & 5 & 6 & 6 & 5 & 5 & 5 & 5 \\
\hline
\end{tabular}

Tabel 6. Nilai pH awal dari ketiga sediaan masih dalam rentang $\mathrm{pH}$ kulit. Sediaan yang disimpan pada suhu ruang cenderung berubah- ubah, terjadinya penurunan dan kenaikan yang bervariasi selama pengujian. Pada formula 1 terjadi perubahan $\mathrm{pH}$ di minggu ke-2 yang di simpan pada suhu ruang $\left(15-30^{\circ} \mathrm{C}\right)$. Pada formula 2 dan formula $3 \mathrm{pH}$ sediaan masih stabil. Sedangkan pada sediaan serum yang disimpan di suhu dingin $\left(2-8^{\circ} \mathrm{C}\right)$ ketiga formula tidak mengalami perubahan $\mathrm{pH}$. Perubahan $\mathrm{pH}$ sediaan selama penyimpanan menandakan kurang stabilnya sediaan selama penyimpanan. Ketidak stabilan ini dapat merusak produk selama penyimpanan atau penggunaan. Perubahan nilai $\mathrm{pH}$ akan terpengaruh oleh media yang terdekomposisi oleh suhu tinggi saat pembuatan atau penyimpanan yang menghasilkan asam atau basa. Asam atau basa ini yang mempengaruhi $\mathrm{pH}$. Selain itu perubahan $\mathrm{pH}$ juga disebabkan faktor lingkungan seperti suhu, penyimpanan yang kurang baik, kombinasi ke tiga ekstrak yang kurang stabil dalam sediaan karena teroksidasi [6].

\section{PEMBAHASAN}

Buah tomat dan kayu manis diperoleh langsung dari pasar rebo daerah Purwakarta. Bagian yang akan digunakan dari buah tomat adalah buah tomat yang masih segar sedangkan untuk kayu manis yang digunakan dalam bentuk bubuk. Dalam penelitian ini pembuatan serum langkah pertama membuat ekstrak sari tomat dan ekstrak kayu manis, kemudian dilakukan tahap formulasi. menggunakan tiga formulasi yang berbeda-beda, masingmasing formulasi dibuat dengan 3 (tiga) sampel untuk diuji pada kondisi penyimpanan yang sama dengan suhu kamar selama 3minggu.
Pembuatan Sediaan Serum Antioksidan dari Ekstrak Sari Tomat (Solanum lycopersicum L.) dan Ekstrak Kayu Manis (Cinnamomum burmannii) dimulai dengan proses pembuatan ekstrak sari buah tomat merah dan ekstrak kulit kayu manis, kemudian masukan bahan sesuai dengan formulasi. Langkah selanjutnya membuat basis serum. Kemudian semua bahan di campur dalam mortir dan dimasukan dalam wadah.

Pengujian organoleptik sediaan selama 3 minggu dilakukan dengan cara mengamati sediaan pada suhu ruangan yaitu $15-30^{\circ} \mathrm{C}$ dan suhu dingni $2-8^{\circ} \mathrm{C}$ dengan tujuan untuk menguji kestabilan sediaan dan memastikan tidak terjadinya perubahan bentuk, warna, bau, rasa, maupun tumbuhnya jamur didalamnya. Hasil yang didapat selama tiga minggu menunjukan bahwa adanya perubahan dalam hal tekstur dan aroma serum. Perubahan ini dikarenakan penurunan mutu sediaan yang dapat disebabkan oleh beberapa faktor diantaranya penguapan yang menyebabkan aroma berkurang, kurang sterilnya pada proses pembuatan sediaan dan perubahan suhu menyebabkan perubahan tekstur sediaan.

Penelitian ini merupakan suatu penelitian pengembangan yang berupa pembuatan sediaan serum dari bahan herbal yang digunakan sebagai antioksidan. Bahan herbal yang digunakan yaitu buah tomat dan kayu manis yang dibuat kedalam bentuk sediaan serum yang bisa digunakan lebih praktis. Penelitian ini hanya sebatas melakukan pengujian organoleptis terhadap sediaan yang telah dibuat, meliputi pengamatan terhadap tekstur, warna dan aroma pada sediaan yang dilakukan selama tiga minggu. 


\section{SIMPULAN}

Dari hasil uji organoleptik formula unggulan adalah formula 2 dan 3 yang di simpan di suhu ruang $\left(15-30^{\circ} \mathrm{C}\right)$ dan formula 1, 2 dan yang di simpan di suhu dingin $\left(2-8^{\circ} \mathrm{C}\right)$ masih dalam keadaan sangat baik. Hasil uji organoleptik di suhu kamar $\left(15-30^{\circ} \mathrm{C}\right)$ menunjukan pada hari ke-9 terdapat perubahan tekstur sediaan pada formula 1, sedangkan ketiga formula yang di simpan pada suhu dingin $\left(2-8^{\circ} \mathrm{C}\right)$ tidak terjadi perubahan sama sekali. Berdasarkan uji kesukaan produk unggulan adalah formula 1 sebanyak 93,3\% suka dengan tekstur serum, 97\% suka dengan warna dan aroma sebanyak $83,3 \%$ suka pada formula 2.

Dari ketiga formulasi selama pengamatan 3 minggu masih dalam keadaan homogen karena tidak terdapat butiran kasar dalam sediaan. Berdasarkan uji $\mathrm{pH}$ sediaan yang paling stabil yaitu yang di simpan pada suhu dingin $\left(2-8^{\circ} \mathrm{C}\right)$. Formulasi sediaan menghasilkan nilai $\mathrm{pH}$ yang berbeda, tetapi tidak mempengaruhi sediaan karena $\mathrm{pH}$ yang dihasilkan tidak masih dalam rentang $\mathrm{pH}$ kulit dan tidak melampaui basa.

Disarankan untuk peneliti selanjutnya untuk melanjutkan penelitian dengan melakukan uji coba serum pada kulit wajah secara langsung. Dan disarankan juga penelitian lebih lanjut untuk mencari formula serum tomat dan kayu manis yang lebih baik.

\section{DAFTAR PUSTAKA}

1. Franceschi, S., E. Bidoli, C. LaVeccia. R. Talamini, B. D'Avanzo, and E. Negri. (1994). Tomatoes and Risk of Digestive-tract Cancers. International Journal of Cancer. 59: 181-184.

2. Gunawan, Adi W. (2007). Genius Learning Strategy. Gramedia Pustaka Utama.

3. Indradewi, F., Hasnawati., \& Sirait, M. (2015). Formulasi Sediaan Masker Gel Peel-off Antioksidan dari EkstrakSari Tomat (Solanum lycopersicum L. var. cucurbita). Jurnal Farmasi, Sains, dan Kesehatan ISSN 2442-9791.

4. Lestari, T (2002) "Hand and Body Lotion: Pengaruh Penambahan Nipagin, Nipasol dan Campuran Keduanya terhadap Stabilitas Fisika dan Efektifitasnya sebagai Anti Jamur". Skripsi: Fakultas Farmasi Universitas Gajah Mada, Yogyakarta.

5. Wirajayakusuma, H. (1998). Hidup Sehat Cara Hembing. Cetakan ke-1). Edisi ke-15, PT. Elex Media Komputindo Gramedia.

6. Young, Anne, (2002). Practical Cosmetic Science, 39-40, Mills and Boon Limited, London. 